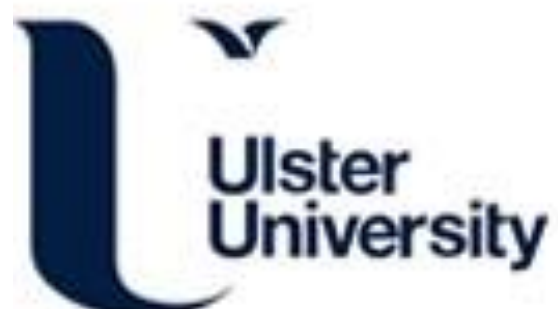

Change management in Northern Ireland's transformed integrated schools:

McGuinness, S. J., \& Abbott, L. (2020). Change management in Northern Ireland's transformed integrated schools: What we want is a school where you can be who you are and it's a safe place. International Journal of Inclusive Education, 1-16. https://doi.org/10.1080/13603116.2019.1707887

Link to publication record in Ulster University Research Portal

\section{Published in:}

International Journal of Inclusive Education

Publication Status:

Published (in print/issue): 03/01/2020

DOI:

https://doi.org/10.1080/13603116.2019.1707887

\section{Document Version}

Publisher's PDF, also known as Version of record

\section{General rights}

Copyright for the publications made accessible via Ulster University's Research Portal is retained by the author(s) and / or other copyright owners and it is a condition of accessing these publications that users recognise and abide by the legal requirements associated with these rights.

\section{Take down policy}

The Research Portal is Ulster University's institutional repository that provides access to Ulster's research outputs. Every effort has been made to ensure that content in the Research Portal does not infringe any person's rights, or applicable UK laws. If you discover content in the Research Portal that you believe breaches copyright or violates any law, please contact pure-support@ulster.ac.uk. 


\section{Change management in Northern Ireland's transformed integrated schools: what we want is a school where you can be who you are and it's a safe place}

\section{Lesley Abbott \& Samuel McGuinness}

To cite this article: Lesley Abbott \& Samuel McGuinness (2020): Change management in Northern Ireland's transformed integrated schools: what we want is a school where you can be who you are and it's a safe place, International Journal of Inclusive Education, DOI: 10.1080/13603116.2019.1707887

To link to this article: https://doi.org/10.1080/13603116.2019.1707887

曲 Published online: 03 Jan 2020.

Submit your article to this journal $₫$

View related articles

View Crossmark data $\nearrow$ 


\title{
Change management in Northern Ireland's transformed integrated schools: what we want is a school where you can be who you are and it's a safe place
}

\author{
Lesley Abbott and Samuel McGuinness
}

School of Education, Ulster University, United Kingdom of Great Britain and Northern Ireland

\begin{abstract}
Historically, Northern Ireland pupils have attended religiously separate schools, however, a movement by parents in the early 1980 s to educate them together resulted in integrated schools becoming part of the educational landscape. Some were new and planned (Grant Maintained Integrated (GMI)) and a second group on which this article focuses sought integrated status through a formal, distinctive process of transformation (Controlled Integrated (CI)). Interviews with Head Teachers in nine transformed schools (primary and post-primary) showed varied reasons for transforming; parents were mostly receptive but needed information and reassurance; and teachers' reactions were largely positive, promoting the integrated ethos by addressing difference and meeting the needs of the minority group with concomitant benefits. Changes in leadership style were attributed to different management structures with Boards of Governors, teachers and parents being much more part of decision-making. There were numerous, varied challenges in the Head's new role, although most could be met, and transformation remained a journey rather than a discrete, one-off change.
\end{abstract}

ARTICLE HISTORY

Received 18 August 2019

Accepted 17 December 2019

\section{KEYWORDS}

Change management; Head teachers; transformed integrated schools

\section{Introduction}

Northern Ireland has had a religiously divided education system since the 1920s and, prior to 1921 and Partition (the inception of Northern Ireland), most primary (national) schools in Ireland were denominational and controlled by the churches. The Lynn Committee's report was the basis of the Education (Northern Ireland) Act 1923. Although invited by the then Education Minister, the Unionist, Lord Londonderry, the Catholic Church declined to be represented, stating that 'the only satisfactory system of education for Catholics is one wherein Catholic children are taught in Catholic schools by Catholic teachers under Catholic auspices' (Akenson 1973, 52). Protestant churches transferred control of their schools to the state while Catholic churches retained control of theirs over the next two decades, hence, 'state controlled de facto Protestant' and 'Catholic maintained' management types, respectively, thus a separate system.

CONTACT Lesley Abbott $@$ l.abbott@ulster.ac.uk $\Theta$ School of Education, Ulster University, United Kingdom of Great Britain and Northern Ireland 


\section{Prelude to integrated education}

Violence and political unrest in Northern Ireland over decades have meant that 'everyday experiences are still shaped by segregation and division' (Blaylock et al. 2018, 644). In fact, 'issues of national identity and constitutional disagreements [dominate] daily life and virtually all elements of civic society are mediated through this lens' (Irwin 2019, 1). In 1974, concerned parents founded All Children Together (ACT) believing that the potentially harmful effects of religiously separated education contributed to the conflict (McGlynn et al. 2004). Although denominational education was not perceived as the sole reason for hostilities, it has 'played a major part in children and young people leading parallel lives' (Abbott 2010, 846). These parents wanted Catholic and Protestant children, and those of other religions or none, to be educated together, and in 1981 their 'dream' was realised when the first integrated school opened in Belfast with 28 pupils (Wardlow 2003, 1). Integrated schools did not 'owe their existence' to the local education authorities, the Department of Education or the churches, but to parents willing to 'undertake the task' (Morgan et al. 1992, 13), and parental involvement on different levels was 'specifically encouraged' (19).

The Northern Ireland Council for Integrated Education (NICIE) was established in 1987 with the remit inter alia of 'coordinating efforts to develop integration; supporting parents through the process of opening new schools; and influencing and informing the public' (Perry 2016, 6). The Department of Education (DE) was required by the Education Reform (Northern Ireland) Order 1989 to encourage and facilitate integration, and to provide grants to bodies aiming to do so. Moreover, the 1998 Belfast (Good Friday) Agreement undertook to uphold and promote it.

\section{The wider picture}

More widely, Taysum (2016) studied how educational leaders in the USA and England used research activity to inform strategies to guide their schools towards cultural alignment. She believed that this enabled the leaders to provide opportunities for assessment of personal and professional narratives and construction of the narrative capital essential to move beyond old scripts, and to envision objective realities around social mobility and civic engagement.

Khalid (2015) examined how Israel's Jewish and Arab school leaders perceived their role in promoting equitable education to bridge socio-economic and pedagogic gaps, questioning how Jewish and Arab Principals understand the concept of social justice and how they promote this in their schools. He contended that Israeli education policy perpetuates ethnic and social gaps, hence, the Principals used a range of strategies like those encountered in the Northern Ireland study to promote social justice. Khalid also noted that Shoho (2006) earlier suggested that success in such a process is predicated on the need for the school's resources to be distributed equitably to empower personal potential. In her US study, Mansfield (2013) argued that 'the main effort of the school leaders should be invested in the transformation of the school culture to a more democratic, participatory and containing society' (646).

\section{The aim of integrated schools}

A broad philosophy of inclusion catering for the needs of all pupils, particularly those with special needs, has attracted sustained global interest (Ainscow 1999; Hegarty 2001; Moran 
and Abbott 2006; Mackey 2014). Recently, Florian $(2019,696)$ observed that 'the use of the term has broadened over the past 25 years' in 'the many different socio-cultural-historical contexts in which schooling occurs' adding that inclusion is not easy. Similarly, 'integration' was mainly interpreted as concerning additional needs (DfES 2003). While the inclusive ethos in Northern Ireland's integrated schools fully reflects this, it goes much further and embraces acceptance of, and respect for, different religions as well as providing for ethnicity, class, gender, ability, experiential history and dispositions. In a context of protracted violence where being 'different' was often perceived as a threat, the creation of 'a culture of silence' denied any meaningful opportunity to explore difference (Wardlow 2003, 2). Marriott $(2001,8)$ warned that respecting others' viewpoints requires first understanding then valuing them which can 'provoke fierce dispute', so integration was not pursued 'naively' (McGuinness, Abbott, and Cassidy 2013, 183). Indeed, bias is 'a normal part of life and an awareness of bias is crucial to ensuring inclusivity' (NICIE, IFI, and EFF 2014, 8).

Integrated schooling aims to provide a quality education through structures comprising a balanced religious intake of pupils, staff and governing bodies, and the pursuit of anti-bias policies (NICIE, IFI, and EFF 2014). Diversity and difference are welcomed, thereby upholding a key element of inclusion. Integrated schools have pioneered a unique model of inclusive practices 'not confined to religiously shared education', since its principles subscribe to inclusion in the widest sense (Abbott 2010, 856). Current integration policy means developing a model of 'equality, diversity, respect and reconciliation through educational excellence' (NICIE 2019, 11) and further promoting transformed schooling.

\section{Types of integrated school}

The origins of the first integrated schools lay in concerned parents testing local opinion, developing an action plan aided by NICIE, and addressing the complex issues of location, funding and staffing (Smith 2001). They were GMI or new, planned integrated schools and are managed by Boards of Governors (the employing authority) as well as representatives of parents, teachers and members appointed by the DE (EA 2019). DE has a statutory obligation to foster integrated schooling and GMI schools were required to have a ratio of 40:40:20 (Catholic, Protestant and 'other') (Blaylock et al. 2018). There are 40 such schools (25 primary, 15 post-primary) (NICIE 2018).

A second group on which this article focuses, consists of state-controlled de facto Protestant schools with mixed enrolment that have transformed to integrated status (currently 25: 20 primary, 5 post-primary), described as Controlled Integrated (CI). Lundy (2000, 278) describes the transformation as 'a procedure [that allows] existing schools to convert to controlled integrated status and thus qualify for mainstream funding'. She was unequivocal, though, that no Catholic school would consider transforming - 'given the composition of the Board of Governors and general ethos in Catholic maintained schools, it is extremely unlikely that a Catholic maintained school will ever seek integrated status' (Lundy 2000, 282). However, almost two decades later, parents in two Catholic primary schools in Northern Ireland have voted for transformation and three Republic of Ireland rural primary schools are seeking 'multidenominational' status, all otherwise facing closure (Irish News, August 28, 2019).

Transformation was endorsed by the $\mathrm{DE}$ as 'a more financially prudent way to extend integrated education' (DENI 1999, in McGonigle, Smith, and Gallagher 2003, 2). 
Management and funding are through the Education Authority via Boards of Governors (EA 2019). Transformation is a slow, complex process, though, in this particular postconflict society (Topping and Cavanagh 2016). Gallagher $(2019,8)$ observed, 'The integrated sector has continued to grow, albeit largely through the transformation of existing schools', agreeing that it was 'not a viable prospect to open new schools at a time of falling rolls' (8). He sees it as 'a rare example of a sector that came into being largely because of the commitment and energy of parents', adding that it remains small 'with limited prospects for growth unless some imaginative new approach can be developed' (32).

Today, 65 planned and transformed integrated schools educate more than 23,600 pupils, just under 7\% of the school population (DE 2019a). Between September 2017 and 2018 , there was $6 \%$ growth in pupils attending integrated schools and with continued parental demand 'at least $40 \%$... have sought or are currently seeking a permanent and/or temporary increase in their enrolment numbers in this past year' (NICIE 2018, 3). This progress is set against $85 \%$ of primary and post-primary schools in Northern Ireland being so separated that that they educate less than $10 \%$ of pupils from the other religious background, many with pupils from one religion (DE 2019b).

\section{Why transform to integrated status?}

Reasons for pursuing transformed status can be pragmatic (falling rolls) and/or philosophical (a wish for integrated ethos and practice). The first schools transformed in 1991 (one primary, one post-primary) (DE 2005). Whilst the philosophical implications are clear, Marriott $(2001,33)$ described the 'more difficult path of ... transforming', stating that, 'Unlike new [planned] schools which have no pre-existing ethos as they are created from scratch ... transforming schools are inherently perceived as schools of "one tradition"'. This was underlined by Topping and Cavanagh $(2016,60)$ : 'Transforming a school, in contrast requires an incremental widening of a long-established culture'. Thus, for more effective, efficient transformation, 'a clear and consistent understanding of the rationale, aims and roles of all the potential actors involved in the process' must exist (McGonigle, Smith, and Gallagher 2003, 21).

\section{The transformation process}

The DE provides detailed guidance on the statutory transformation process (DE 2017), including having a minimum of $10 \%$ of the minority tradition at the outset, aiming for at least $30 \%$ (34) and culminating in a secret ballot of parents through The Electoral Reform Services (ERS) in London. Achieving a religious balance takes time, but the potential benefits for pupils are substantial in a setting where understanding of, and respect for, difference can be explored, endorsing the Government's commitment to A Shared Future 'Our strong belief is that Northern Ireland must become a society where there is equality, respect for diversity and a recognition that we are interdependent on each other' (OFMDFM 2003, n.p.).

\section{A model for integration}

Putting integration into practice is reflective of Kincheloe and Steinberg's (2001) models of multiculturalism who saw a spectrum, not a single definition. Multiculturalism may imply 
'a goal, a concept, an attitude, a strategy and a value' (1) and, while they focused on race, class and gender, this was not 'a dismissal of other forms of diversity' (2) and could apply to educational settings. For integrated schooling, this means avoiding prejudice of any kind for, as well as religious differences, Northern Ireland has an increasingly multicultural population.

First, the monoculturalism model usually signifies a belief in the superiority of one culture. Second, liberal multiculturalism accepts that all are equal regardless of background with a 'focus on sameness' (Kincheloe and Steinberg 2001, 15), difference is subsumed into the dominant culture, and no hard conversations are addressed. Third, pluralist multiculturalism recognises diversity as 'intrinsically valuable' (15) but considers it in isolation from its context. However, a fourth model, critical multiculturalism, acknowledges difference and uniqueness and supports sensitive dialogue, an agenda which integrated schools actively pursue (ETI 2007). In respecting another viewpoint or a cultural or religious practice, Marriott stressed that, ' ... one first has to understand it then value it ... Respect does not mean agreement, ... but it does mean taking other people and their beliefs and actions seriously' $(2001,8)$. McGlynn $(2003,22)$ thought integrated schools could become 'even more effective by adopting models of critical multicultural education'.

Wardlow (2003) does not blame religiously separate schools for sectarian attitudes, but believes that if teachers, parents, pupils, governors and ancillary staff from different cultural backgrounds can meet in a safe, managed space, then true integration can be achieved 'where individuality is not denied in favour of some form of bland homogeneity' (3). Recently, Gallagher et al. $(2019,3)$ reiterated that 'education is not a direct cause of violent conflict', but could 'determine attitudes, values and behaviour across generations' (3). They stated that 'pupils in integrated schools have been found to have more positive attitudes towards the outgroup, more moderate positions on political and constitutional issues and greater respect for the other group's culture and religion' than those in denominational schools (11).

\section{Change management during transformation}

The principle of inclusion is seen as a key challenge for forms of school leadership (Ainscow and Sandill 2010, 414) 'with the principal seen as a leader of leaders'. Leading and managing transformation is a major educational undertaking and is not without 'turbulence' (Shapiro and Gross 2013). Change is seen as 'ubiquitous, and so is the concept of change' (Altrichter and Elliott 2000, 2) and the challenge for school leaders in Northern Ireland is '[bringing] about changes that are sustained and make a real difference in the quality of learning and life for the pupils, teachers and wider school community' (DE 2017, 27).

McGuinness et al. (2019) found that leaders who conveyed lucidity around the school's vision and led in such a transformational manner that they generated passion in their followers, developed personal and group empowerment to engineer change and minimise any detrimental effect of turbulence (Gross 2016). Moreover, one of the strongest reported success criteria regarding the change journey concerned the leader developing intentionality in initiating positive relationships with other players, whether pupils, colleagues, parents or other Heads through school partnerships (McGuinness 2012). This paper examines the journey towards integration being made by nine schools centred on 
philosophy becoming practice which shows respect for individuality and a culture of collaboration (Skrtic 1991).

\section{Method}

\section{Aims and objectives}

The research aim was to determine how change aspects were managed by Head Teachers in transforming schools. The objectives were to determine the reasons for, and experiences of, seeking integrated status; to understand parents' attitudes towards transformation, teachers' reactions to integration and how they promoted it; to identify opportunities, changes made (curriculum, school emblems), benefits and challenges; and to pinpoint changes in Heads' leadership style as they became more collaborative and participative to facilitate engagement.

\section{Sample}

The intention was to select 10 schools, five primary (ages 5-11) and five post-primary schools (ages 11-18), the single criterion being that Head Teachers were in post during the transformation process. There were 14 primary and five post-primary schools rendering sample selection using this variable viable in the former but not the latter sector. Two post-primary schools were included and, in collaboration with NICIE, two retired Heads with extensive experience of transformation were interviewed, giving a sample of nine (5 primary, 4 post-primary). Primary school enrolment ranged from 31 to 230 and postprimary from 320 to 900 . The first school visited in each sector was used for pilot purposes with the data also included in the main study. Five participants were female, four were male and all were Protestant. One Key Stage Head was nominated for the interview since the current Head was not in post when transformation began.

\section{Research design}

A qualitative approach was chosen to seek Head Teachers' experiences of their schools' transformation process as it can elicit 'vivid and richly detailed accounts of human experience' (Ary et al. 2006, 485), and can generate themes and identify similarities and differences (Cohen, Manion, and Morrison 2011). The research instrument was the one-to-one, semi-structured interview, frequently used to obtain qualitative data and felt to be 'fit for purpose' since the study sought to gather 'unique, non-standardized, personalized information' (412).

Each audio-recorded interview lasted approximately one hour and was transcribed verbatim for content analysis. Following Braun and Clarke (2006), the transcriptions were repeatedly scrutinised for immersion in the data, 'the bedrock of the rest of the analysis' (87). This identified common patterns, meanings and relevant sub-themes that were classified thematically under predetermined headings derived from the interview questions, manually coded and collated. Verbatim extracts illuminated commonalities and sub-themes. Careful consideration was given to Corden and Sainsbury's (2006) advice that such quotes should reflect positive and negative viewpoints. 
Full ethical approval in keeping with BERA's (2004) guidelines was granted by the University's Research Ethics Committee (the wider study included primary and post-primary pupils). All possible precautions were taken to ensure confidentiality and anonymity. Contextual clues to collective and individual identity were removed since 'the people who are in a position to identify individuals are exactly those to whom exposure has the greatest potential risks of harm or embarrassment' (Walford 2005, 88), hence, school sector only was indicated in selected quotes (primary (p), post-primary (pp)).

\section{Findings}

\section{Reasons for seeking transformed status}

Three of the nine schools transformed because of falling rolls and financial difficulties (2p, $1 \mathrm{pp})$ - ' ... a cost-effective option to keep the school afloat' (p). Three were informally integrated and wished to formalise their status (2p, 1pp), the others seeking to engage with the integrated ethos and to consolidate an already mixed enrolment in this way (1p, 2pp) - 'It seemed to offer something very profound and very, very powerful' (pp).

The journey started because our local children came from a very mixed community ... religiously quite balanced because a lot of the Army [stationed here] have Catholic families. In the little island of security we can provide, we're trying to make them feel it's very normal for children of different faiths to grow up and be taught together. (p)

\section{Parents' attitudes towards transformation}

Parental attitudes were largely positive although seven Heads reported some problems (5p, $2 \mathrm{pp}$ ), deemed not serious by four and easily resolved with no pupils being removed ( $2 \mathrm{p}$, $2 \mathrm{pp}$ ) - 'I wouldn't over-stress the parental opposition ... very little. Certainly, none was organised' (pp). It depended on the school's catchment area and whether integration was perceived as a threat or benefit - 'Not an easy process' ( $\mathrm{p})$. There was considerable onus on the Head to allay parental fears - 'Quite heated debates ... part of a dark time that people don't want to reflect on' (p).

... a feeling among some parents that their culture was going to be washed away ... felt threatened. As a transformed school, it's a balancing act between making sure that you're welcoming to the Catholic minority, while still acknowledging the broad number who want a Protestant education for their children. (p)

It was crucial to inform parents fully and in a measured way at every stage of the process to 'meet their concerns' (p). Reassurance was vital 'because it could have all gone very badly wrong had it not been so sensitively handled' (p).

\section{Teachers' reactions}

All nine Heads said that teachers initially promoted the spirit of integration to varying degrees, whereas they now addressed difference and worked actively in the area of conflict resolution if problems arose (5: 4p, 1pp). They fostered the ethos through different projects (3: $2 \mathrm{p}, 1 \mathrm{pp})$ and used circle time and peer mediation in primary and 
post-primary schools, respectively, to engage with sensitive issues (2: 1p, 1pp). Progress, though, was gradual.

The [curriculum] requires you to move children forward from ... personally addressing issues about people different from themselves, in religion or physically or skin colour... how you cope with anger, or with people who bully you. (p)

A post-primary Head reporting a spectrum of staff attitudes during transformation, witnessed initial indifference become deep commitment.

Some people wanted to preserve their jobs and didn't care if it was an integrated school. Some were just interested in teaching, others strongly favoured integration. Post-integration ... an expectation on staff to introduce the integrated ethos into the classroom and explain how they did so. (pp)

Two Heads (1p, 1pp) admitted that staff composition could affect integration, with those already in post possibly less committed. However, academic standards remained of prime importance.

... an inherited staff who may agree with transformation but can be perceived by new [teachers] or new parents as not having changed. A [transformed] school is not just about religion and if you don't have a high standard of education, no parent is going to sacrifice their child on the back of integration. (pp)

\section{Opportunities and changes following transformation}

\section{Opportunities}

Opportunities were philosophical and pragmatic. Four Heads wanted to prepare pupils for a future based on the meaning, principles and underlying rationale of integrated education (3p, 1pp) - 'How are these young people going to move forward otherwise?' (pp). More pragmatically, two saw the prospect of increasing pupil numbers (1p, 1pp). Two primary Heads highlighted religious provision for Catholic pupils in a previously Protestant school - 'The very basic opportunity was that we could offer the sacramental training ... caused problems for some, particularly from the local [Catholic clergy]' (p). However, there was now acceptance, with children prepared by a teacher for the sacraments $(p)$.

Two participants saw the chance to develop and maintain stronger links with local separated schools. One primary school now proactively recruited teachers who wanted to 'live integration'. More Catholic teachers could be recruited - ' ... far more Catholics applying for the jobs and, by probability, more appointed' (pp).

Every single one of them when interviewed thought integration was 'absolutely wonderful' ... but they were looking for a job.... others were pushing the parameters. (pp)

\section{Changes}

Numerous changes followed transformation concerning the curriculum and outward signage and emblems, although educational standards took priority. First, the Northern Ireland Curriculum (NIC) must be followed 'otherwise you'll not get parents coming to your school' (p), but some elements were added, mainly in Physical Education (PE) and Religious Education (RE), both raising parental concerns, for example towards the 
introduction of traditionally Catholic sports in a previously Protestant setting. Previously, schools offered hockey, cricket and rugby, then added Gaelic football, hurling and camogie - 'I explained why and that was accepted ... and the [parents] stayed' (p). Transferable, key skills created common ground and pupil choice was strongly underlined 'Occasionally individuals would object, usually out of ignorance, because they'd swallowed the line that this was compulsory' (pp).

Whilst RE conformed to the NIC core elements, it also included broader engagement with other world religions and festivals - ' ... it might take two or three years with a composite age class ... a rolling programme so it might be the Chinese New Year, next Diwali' (p). One primary Head noted that although bringing pupils together was part of the transformation process, paradoxically, 'We send the Protestants one way to a lesson and the Catholics another. To me, that's not what integration's about ... bringing them together to separate them again' (p). One religious denomination did not allow pupils to eat with those of other faiths, so appropriate, yet seemingly exclusionary, arrangements were made.

We looked at the core syllabus agreed by the Catholic church and the Protestant denominations. ... to accommodate any preparation [required] for the sacraments ... I had a Church of Ireland minister who worked with children for their First Communion ... other children who are Hindus have to have time out to visit a Hindu temple. (p)

Post-primary colleagues referred to 'a common curriculum for RE', to 'a syllabus very much defined by GCSE at Key Stage 4 (14-16 years)', and to 'having a Head of Department who was even-handed [hence] no parental complaints' (pp). One parent complained about the rosary in the classroom and was advised that it was something we have to explore for all' (pp). Another Head thought the RE syllabus 'took the sting out of the tail' of transformation and set up 'denominational care'. Changes also related to History with the introduction of, or increase in, the teaching of Irish history. All schools included Irish authors and publishers following transformation.

Second, all nine schools changed their name to indicate integrated status, and four from both sectors mentioned uniform changes including an altered badge sometimes with 'elements of the old' (pp). Regarding after-school football kits associated with different religions, 'We thought, "No. What we're trying to teach them is tolerance, so we'll accept any kit". Didn't ban anything' (p). Conversely, one post-primary school took the opposite stance as they perceived 'tribal echoes' and introduced a neutral kit (pp).

Tough decisions arose over the highly sensitive issue of national flags in school grounds.

The most difficult thing in the action plan I left to the last minute - the removal of the Union flag, but no parents or pupils commented. A risk but it worked. We made a school flag and [notified] the Department of Education. (pp)

I've purchased national flags ... 21 different nationalities ... a welcome booklet for all ethnic minority communities for whom English is a second language. (p)

One school elected to have no flag, seeing it as 'divisive' - 'What we want is a school where you can be who you are and it's a safe place' (p). Diversity on notice boards was 'more integration-related' (p), resulting in a move beyond merely uniting Catholic and Protestant - ' ... whenever we brought in additional families from Poland, Slovakia, Pakistan, we had to look at ourselves as much more than just two communities' (p). 
All Heads underlined the gradual emergence of these outward signs, with welcome support from NICIE on how to proceed with the two central strands, ethos and the curriculum - ' ... a bit of a fallow period of about a year after integration ... kind of flailing in the dark' (pp). One audited everything in school to perceive any 'cultural deficit - "What should we be doing?"' (pp). It was a unique opportunity for children 'to be guided by sensible people to allow them to get a sense of self-worth' (p), but there were some misgivings about whether completely inclusive integration could be achieved within a separate education system and, crucially, a still divided society beyond.

... I don't think this school will ever be a fully inclusive integrated school. I don't think any community of people in a place like Northern Ireland will ever be, and I highlight it around the world in the different faiths and different communities. (p)

\section{Benefits and main challenges}

\section{Benefits}

Benefits were various at all levels and although Northern Ireland was not 'a normal community' (p), integration was a chance 'to celebrate diversity' (p). All five primary Heads stressed understanding and accepting difference, allied to meeting the needs of children of the minority or any tradition or ethnicity: 'Nice to think it's normal to be mixed'(pp).

It's now OK to say, "You made your First Communion or You're black". One of the little girls we have is black and [the others] actually go up and touch her and go, "I could do this with your hair” and that's fine [but] the novelty's gone. Just acceptance now. (p)

Three referred to advantages for teachers $(2 \mathrm{p}, 1 \mathrm{pp})$ with integration to the forefront and opportunities for 'tremendous staff development' (pp). Two reiterated the advantages of increased pupil numbers (1p, 1pp).

If you were very hard-nosed, you'd say ... in a very clinical way one of the main benefits. But there's a [new] sense of vibrancy and a buzz about the school. (p)

Pupils' understanding of integration was a benefit going beyond the school setting in a more enduring way and pupil friendships formed -'So nice to see them playing together with religion not even an issue ... to see the bigger ones forming friendships they take into secondary school' (p).

\section{Main challenges}

Challenges arose, some serious, others manageable but ongoing. First, the lack of support for integration from the Catholic clergy caused an imbalance among the Board of Governors.

My biggest difficulty would be [that] the Catholic Church won't give us their two representatives.... Our Board of Governors nominate two people in lieu of Catholic trustees ... [we] try to pick people from the Catholic community. (p)

... a lot of individual Catholic priests have supported us in different ways ... not a wrong thing for children to learn to live together, but the Catholic church has its own schools, it's trying to keep its numbers, and feel it's purer to provide Catholic education in Catholic schools by Catholic teachers. (p) 
Second, the momentum of the integrated ethos had to be sustained (1p, 1pp), highlighting the importance of acceptance in the wider community and 'keeping the parents on board' (2pp). Change had to be made in a measured way (1p, 1pp) - 'The challenge is that you, by being enthusiastic ... have to walk in others' shoes. If you try to railroad people into doing things your way, it'll never work' ( $p$ ). Third, the twin needs were underlined for 'marketing' to retain the religious balance, and for earning the trust of parents in the minority tradition.

When you first transform, you have a community which opens its arms, but you have to earn trust ... give their children what they expect you to give them. Would you trust your child to a strange environment? It's a heck of a leap. (pp)

Additionally, being inspected as an integrated school was a different experience, particularly in a divided society - ' ... made us review what we'd done' (pp).

Ten years ago, it would have been impossible because of paramilitary activity in the area ... (pp)

\section{Changes in heads' leadership style}

Opinion was divided as to whether Heads' leadership styles had altered. Four identified changes (4: 1p, 3pp) and four did not (4: 3p, 1pp). Here, the sample was reduced by one (see methodology).

\section{Some changes}

The main change was the different management structure since Heads came from a 'completely autocratic system', whereas now there was a much greater teacher and parent participation in decision-making. For transformation to work, they had to adjust, build trust, demonstrate clarity of vision, show enthusiasm and motivational leadership, as well as capitalising on staff skills. Leading change, however, was deemed highly positive.

Previously, consultation just didn't exist ... very powerful in career and personal development [because] leading change is leading people. (pp)

Teachers have to be part of the decision-making process and our senior management team has a much flatter structure. We encourage staff to participate at all levels. (pp)

... I'm a great believer that if you have a good staff, you use the talent. (pp)

My style of leadership has suited my needs. It's me and the staff ... very much a shared, democratic approach to decision-making. (p)

Having parents on the Board of Governors could create demands - 'Although I greatly appreciate and value their input ... some parent governors feel that they have more power and control than they actually have ... they find it very difficult to take their "parent hat" off when they're a governor and vice versa' (p).

Although not exclusive to integrated schools, greater emphasis was now placed on the pupil voice - 'Never underestimate the youngsters' (pp). One Head spoke of a pupil who spent time for academic reasons at a grammar school catering predominantly for one religion, returning to the integrated setting appalled at the sectarian language used - 'Totally 
shocked at the casual bigotry ... realised she hadn't experienced it here because of the integrated ethos [which] wouldn't have been tolerated' (pp).

Increasing enrolment added to the Head's changing role. Further, relationships with local religiously separated schools had to be nurtured because of an unfamiliar sense of belonging to neither 'camp'.

\section{No changes}

Other Heads experienced the same marked differences in management structure but reported no changes in their own leadership style, while acknowledging the quintessence of leading change.

I'm the same person and the start of this journey was ... reflecting on where your school can develop ... already involved in a lot of cross-community work, some fairly cutting-edge stuff ... a project with a Catholic school who are still our best friends. (p)

It's [recognizing] that diverse groups can live together and accommodate each other for the greater good, but without any dilution of their own tradition, cultural background and beliefs - more than just co-existing in a building. (pp)

Heads' own professionalism could be called into question, though, with reference again to parent governors, but they stood firm on the core substance of integration. Some queried staffing decisions and others made demands to benefit their own child - 'I said, "I've listened to what you have to say, but you governors employed me to make this decision ... actually I do know better than you"' (p).

\section{How the study met the aims and objectives}

The research determined how change aspects were managed by Head Teachers in transforming schools, and how their leadership style changed throughout the process. It clearly articulated their reasons for, and involvement in, the journey to integrated status. Parents' attitudes and teachers' reactions to opportunities, benefits and problems along the change journey were reported.

\section{Conclusions}

Altrichter and Elliott $(2000,3)$ suggest that change is like gazing through a kaleidoscope. The image changes quickly ...'. While the structural and cultural nuances around the development of a range of relationships could present obstacles, the personal skill sets of individual players had the potential to build trust, as shown here. The Heads felt empowered by those around them as inter-personal relationships tended to dominate their responses around the positive aspects of leadership, although turbulence could be experienced differently (Shapiro and Gross 2013). Trust was a keystone although establishing this in a post-conflict society can be fraught. It is, however, pivotal to the success of the transformation. Tschannen-Moran and Gareis $(2015,1)$ assert that 'trust becomes salient when people enter into relationships of interdependence, where the outcomes one desires cannot be met without the involvement and contribution of others'.

Head Teachers' positive encouragement of colleagues by sharing knowledge and power through distributed leadership (Harris 2003), and sharing a vision for a better future, were 
employed by some participants to optimise opportunities for creating and managing an integrated school environment. Like this small-scale study, McGuinness et al. (2019) found that those Heads who demonstrated passion in their work and articulated clarity in terms of their vision for building relationships were able to handle the challenges and minimise potentially negative impact.

The interviews showed that leaders who acted openly, intentionally and invitingly in their communication with colleagues, governors and communities were most successful in addressing possible sources of turbulence (Shapiro and Gross 2013). Building support from others was a prerequisite for enabling pupils to be drivers for social change. Continuing professional development was similarly regarded as helping to develop better support structures, as well as fostering relationships with others in school leadership roles across Northern Ireland, extending the support network. The powerful international messages from Taysum (2016), Khalid (2015), Mansfield (2013) and Shoho (2006) and others have resonance with the authors' findings in the current study.

Encouragingly, 'No school that has transformed has ever chosen to revert back to nonintegrated status' (DE 2017, 6). Perhaps this is because, as here, staff and Heads undertaking the journey identify numerous benefits, including broadening pupils' perspectives to prepare for a culturally diverse world. However, effective leadership 'which develops a clear vision for the transformed school' is crucial (DE 2017, 11). Unquestionably, the future of transformed schools is an ongoing process, with progress manifested in having the difficult conversations of critical multiculturalism (Kincheloe and Steinberg 2001). Change management remains exacting and demanding, but also aspirational and inspirational:

Organizational change often sees lucky winners, who came very close to losing it all, but who, once having won, have the means to build up and substantiate their win - gradually to extend the efficiency of their programme - and to rewrite the history and the success criteria of the organization. (Altrichter and Elliott 2000, 4)

\section{Disclosure statement}

No potential conflict of interest was reported by the authors.

\section{Notes on contributors}

Dr Lesley Abbott is an Honorary Fellow of Ulster University and Educational Research Consultant, previously a Research Fellow. She was awarded the Brian Simon Educational Research Fellowship in 2006-2007 by the British Educational Research Association. Her research interests include teacher education and the needs of student teachers, the professional needs of learning support assistants, and children's use of tablet technology.

Dr Sam McGuinness is a former Head of the School of Education at Ulster University. His original research field was organometallic chemistry and his current research interests are in international educational leadership and policy. He presently implements a postgraduate Headship Diploma and a Master's programme in Educational Leadership and Management.

\section{References}

Abbott, L. 2010. “Northern Ireland's Integrated Schools Enabling Inclusion: A New Interpretation?” International Journal of Inclusive Education 14 (8): 843-859. doi:10.1080/13603110902755462. 
Ainscow, Mel. 1999. Understanding the Development of Inclusive Schools. London: Falmer Press.

Ainscow, Mel, and Abha Sandill. 2010. "Developing Inclusive Education Systems: The Role of Organisational Cultures and Leadership." International Journal of Inclusive Education 14 (4): 401-416. doi:10.1080/13603110802504903.

Akenson, Donald H. 1973. Education and Enmity: The Control of Schooling in Northern Ireland 1920-50. Newton Abbot: David and Charles.

Altrichter, Herbert, and John Elliott, eds. 2000. Images of Educational Change. Buckingham: Open University Press.

Ary, Donald, Lucy Cheser Jacobs, Ashghar Razavieh, and Chris Sorenson. 2006. Introduction to Research in Education, Seventh Edition. Belmont, CA: Thomson Wadsworth.

BERA (British Educational Research Association). 2004. Revised Ethical Guidelines for Educational Research. Southwell: BERA.

Blaylock, Danielle, Joanne Hughes, Ralf Wölfer, and Caitlin Donnelly. 2018. “Integrating Northern Ireland: Cross-group Friendships in Integrated and Mixed Schools." British Educational Research Journal 44 (4): 643-662. doi:10.1002/berj.3452.

Braun, Virginia, and Victoria Clarke. 2006. "Using Thematic Analysis in Psychology.” Qualitative Research in Psychology 3 (2): 77-101. doi:10.1191/1478088706qp063oa.

Cohen, Louis, Lawrence Manion, and Keith Morrison. 2011. Research Methods in Education. 7th ed. London: Routledge.

Corden, Anne, and Roy Sainsbury. 2006. Using Verbatim Quotes in Reporting Qualitative Social Research. Researchers' Views. York: Social Policy Research Unit (SPRU), University of York.

DE (Department of Education). 2005. Transformation: An Information Pack for Schools. Bangor: DE.

DE (Department of Education). 2017. Integration Works - Transforming Your School. Accessed April 4, 2019. https://www.education-ni.gov.uk/publications/integration-works-transformingyour-school-guidance.

DE (Department of Education). 2019a. Annual Enrolments at Schools and in Funded Pre-school Education in Northern Ireland, 2018/19. Statistical Bulletin 2/2019. Accessed June 14, 2019. https:/www.gov.uk/government/statistics/annual-enrolments-at-schools-and-in-fundedpreschool-education-in-northern-ireland-201819.

DE (Department of Education). 2019b. School Enrolment - School Level Data 2019/19. Accessed July 25, 2019. https://www.education-ni.gov.uk/node/37331.

DENI (Department of Education for Northern Ireland). 1999. Statistical Data on Schools in Northern Ireland. Bangor: DENI.

DfES (Department for Education and Science). 2003. Every Child Matters. Norwich: HMSO.

EA (Education Authority). 2019. Grant Maintained Integrated Schools. Accessed November 5, 2019. https://www.eani.org.uk/school-management/school-finance/school-finance/grant-maintainedintegrated-schools.

ETI (Education and Training Inspectorate). 2007. Inspection and Improvement - The Chief Inspector's Report 2004-2006. Belfast: ETI.

Florian, Lani. 2019. "On the Necessary co-existence of Special and Inclusive Education." International Journal of Inclusive Education 23: 7-8, 691-704.

Gallagher, Tony. 2019. Education, Equality and the Economy. Belfast: Queen's University.

Gallagher, Tony, Gareth Robinson, Joanne Hughes, and David Connolly. 2019. Education in Conflict-afflicted Areas: Final Report. London: British Council.

Gross, Steven J. 2016. Using Turbulence Theory as a Metaphor in a Volatile World. Accessed October 15, 2019. http://marylandpublicschools.org/about/Documents/PromisingPrincipals/ Resources/102016/2015TTonlytoMd.pdf.

Harris, Alma. 2003. "Distributed Leadership in Schools: Leading or Misleading?" Management in Education 16 (5): 10-13. doi:10.1177/089202060301600504.

Hegarty, Seamus. 2001. "Inclusive Education - A Case to Answer." Journal of Moral Education 30 (3): 243-249. doi:10.1080/03057240120077246.

Irwin, Tracy. 2019. "Further Education and Skills in Northern Ireland: Policy and Practice in a Postconflict Society." Journal of Education and Work 32 (3): 266-276. doi:10.1080/13639080.2019. 1621275 . 
Khalid, Husny A. 2015. "Leadership for Equity and Social Justice in Arab and Jewish Schools in Israel: Leadership Trajectories and Pedagogical Praxis.” International Journal of Multicultural Education 17 (1): 1-26. doi:10.18251/ijme.v17i1.938.

Kincheloe, Joe L., and Shirley Steinberg. 2001. Changing Multiculturalism. Buckingham: Open University Press.

Lundy, Laura. 2000. Education Law, Policy and Practice in Northern Ireland. Belfast: SLS Legal Publications (NI).

Mackey, Megan. 2014. "Inclusive Education in the United States: Middle School General Education Teachers' Approaches to Inclusion.” International Journal of Instruction 7 (2): 1308-1470.

Mansfield, Katherine C. 2013. "II Love These Girls - I Was These Girls': Women Leading for Social Justice in a Single Sex Public School.” Journal of School Leadership 23 (4): 640-663. doi:10.1177/ 105268461302300404.

Marriott, Stuart. 2001. Polite Encounters? Integrated Primary Schools and Community Relations. Coleraine: University of Ulster.

McGlynn, Claire. 2003. "Integrated Education in Northern Ireland in the Context of Critical Multiculturalism.” Irish Educational Studies 22 (3): 11-27. doi:10.1080/0332331030220305.

McGlynn, Claire, Ulrike Niens, Ed Cairns, and Miles Hewstone. 2004. "Moving out of Conflict: The Contribution of Integrated Schools in Northern Ireland to Identity, Attitudes, Forgiveness and Reconciliation." Journal of Peace Education 1 (2): 147-163. doi:10.1080/1740020042000253712.

McGonigle, Julie, Alan Smith, and Tony Gallagher. 2003. The Challenge of Transformation. Research Report, 23 pp. Coleraine: UNESCO Centre, University of Ulster.

McGuinness, Sam. 2012. "Education Policy in Northern Ireland: A Review." Italian Journal of Sociology 1: 205-237. doi:10.14658/pupj-ijse-2012-1-9.

McGuinness, Samuel, Lesley Abbott, and Frank Cassidy. 2013. "Northern Ireland: Some Postconflict Challenges in Education." In School Level leadership in Post-conflict Societies, edited by S. R. P. Clarke and T. A. O’Donoghue, 175-191. London: Routledge.

McGuinness, Samuel, Jessica Bates, Stephen Roulston, Una O’Connor, Catherine Quinn, and Brian Waring. 2019. "Empowering School Principals to Overcome Turbulence in School Partnerships through Governance Systems for Equity, Renewal and Peace: Northern Ireland.” In Turbulence, Empowerment and Marginalisation in International Governance Systems, edited by J-M. Gaetane and A. E. Lopez, 137-158. Bingley: Emerald Publishing.

Moran, Anne, and Lesley Abbott. 2006. The Development of Inclusive Schools in Northern Ireland: A Model of Best Practice. Research Report. Bangor: Department of Education.

Morgan, Valerie, Grace Fraser, Seamus Dunn, and Ed Cairns. 1992. "Parental Involvement in Education: How Do Parents Become Involved?” Educational Studies 18 (1): 11-20. doi:10. 1080/0305569920180102.

NICIE, IFI and EFF (Northern Ireland Council for Integrated Education, International Fund for Ireland and Esmee Fairbairn Foundation). 2014. ABC: Promoting an Anti-Bias Approach to Education in Northern Ireland. 2nd ed. Belfast: NICIE, IFI and EFF.

NICIE (Northern Ireland Council for Integrated Education). 2018. Annual Report 2017-18. Belfast: NICIE.

NICIE (Northern Ireland Council for Integrated Education). 2019. 2018-19 NICIE Directors' Reports and Financial Statements. Belfast: NICIE.

OFMDFM (Office of the First Minister and Deputy First Minister). 2003. A Shared Future: A Consultation Paper on Improving Relations in Northern Ireland. Belfast: OFMDFM.

Perry, Caroline. 2016. Education System in Northern Ireland. Briefing Paper 44/16. Belfast: Northern Ireland Assembly.

Shapiro, Joan P, and Steven J. Gross. 2013. Ethical Educational Leadership in Turbulent Times: (Re)solving Moral Dilemmas. 2nd ed. New York: Routledge.

Shoho, Alan R. 2006. "Preparing Leaders for Social Justice: Overcoming Pathologies of Silence." Journal of Educational Administration 44 (3): 196-208.

Skrtic, Thomas M. 1991. "Students with Special Educational Needs: Artefacts of the Traditional Curriculum." In Effective Schools for All, edited by M. Ainscow, 167-177. London: David Fulton. 
Smith, Alan. 2001. "Religious Segregation and Emergence of Integrated Schools in Northern Ireland." Oxford Review of Education 27 (4): 559-575.

Taysum, Alison. 2016. "Educational Leaders' Doctoral Research That Informed Strategies to Steer Their Organizations Towards Cultural Alignment." Educational Management Administration \& Leadership 44 (2): 281-300.

Topping, Margaret, and Colm Cavanagh. 2016. Integrating Education in Northern Ireland: Celebrating Inclusiveness and Fostering Innovation in our Schools. Bangor: DE.

Tschannen-Moran, Megan, and Christopher R. Gareis. 2015. "Principals, Trust, and Cultivating Vibrant Schools." Societies 5 (2): 256-276. doi:10.3390/soc5020256.

Walford, Geoffrey. 2005. "Research Ethical Guidelines and Anonymity." International Journal of Research \& Method in Education 28 (1): 89-93. doi:10.1090/01406720500036786.

Wardlow, Michael. 2003. In Support of Integrated Education. Belfast: NICIE. 